\title{
研究会抄録
}

\section{第15回 四国小児アレルギ一研究会}

\section{平成 15 年 5 月 31 日（土）}

\section{1. 妊娠週数と I 型アレルギーとの関係について} 徳島市民病院小児科

\author{
○松岡 優, 吉村 栄子, 伊勢 正夫 \\ 小谷裕美子, 宮本 紀子, 久保 賢倫 \\ 山下 和子
}

妊娠週数がアレルギー発症に関与するかどうかを検 討した．対象は妊娠週数 23 週から 28 週未満（10名）, 28 週 33 週未満 (23名)，33 週 37週未満（25名） およびそして妊娠 37 週以上 41 週末満に生まれた正期 産览でアレルギー検查を受けた 26 名を対照（参考）群 とした. [結果]（1）乳児期において，超早期産児は アトピ一性皮膚炎および喘息様気管支炎の罹患率が少 なかった。この傾向は1歳，2歳時の幼児期にも続い た.（2）血清総 IgE 值も早期産児ほど低值で，この傾 向は2歳時にも認められた。

\section{2. 食物糖鎖を现識する特異 $\lg E$ 抗体の役割について} おおた小児科アレルギー科クリニック 太田 展生

食物抗原に対する特異 IgE 抗体は，食物糖鎖を認識 する抗体を含んでいる，今回，10人のアトピー性皮虚 炎の患者に対して，大豆，米，小麦，じゃがいもの糖 鎖を anti-HRP 処理をし，糖鎖に対する反応を抑制して 特異 IgE 抗体を測定した，その結果，糖鎖を認識する 抗体が多いものは，特異 IgE抗体が陽性でも，原因抗 原でない可能性が示唆された.

3. ビタミンA油を配合した新しい非ステロイド性外 用棛のアトピ一性皮虔炎に対する有用性について

香川県立津田病院小児科 ○渡辺 俊之 日本油脂株式会社・内外薬品株式会社

私は，平成6年にアトピー性皮唐炎（AD）治療用と して DHA · EPA 含有軟亳を考案・開発し，その後 8 年 間 $\mathrm{AD}$ の治療に用い，その有用性を学会・論文等で発 表してきた. 平成 13 年に厚生労働省よりビタミンA油 配合の非ステロイド性抗炎症軟育が一般用医薬品とし て承認された、このビタミンA 油には DHA・EPAが含 有されており $\mathrm{AD}$ に有効と考えられます。そこで $\mathrm{AD}$ 患
者を対象に有用性を検討したので報告する.

4. 多種魚類アレルギーを伴ったアトピー性皮膚炎乳 児 3 例の長期予後

国立高知病院臨床研究部 アレルギー科（小児科）

○小倉 英郎，林 晶子，小合由紀子

食物アレルギーを持つアトピー性皮膚炎児の蛋白源 として，魚類を利用することが多い，今回，多種の魚 にアレルギー反応を示す乳児 3 例の長期予後を検討し た.

初診時の経口誘発試験では卵・牛乳・大豆・小麦 ・ 米なども陽性で，米，小麦，大豆，(牛乳) は $1 \sim 3$ 年 で而性獲得したが，現在も魚では即時型反応がみられ て除去を継続中である．なお，蛋白質の攝取は甲殻類， 軟体類，獣肉より行い，栄養・発達に問題はみられて いない.

5. 魚アレルギーについての考察 一魚類 IgE RAST 高值男児例に対する経口負荷を通してー

香川医科大学小坚科

○黒野 由紀，野見紅実子，長野 恵子 川崎 綾子, 岡田 仁, 難波 正則 今井 正, 伊藤 進

魚アレルギーは魚消費量の多い国に多いと言われて おり，わが国も世界有数の魚消費国である．今回我々 は乳児期の魚摄取により膨疹が出現、以降 5 歳時まで 魚類の捸取を制限していた患児に対し，母親の希望に より外来にて経口負荷を施行した例を経験した. この 症例を通してRASTのみにより食物制限をするのでは なく，経口負荷により摂取制限の内容を決定すること が重要と考えられた. 魚アレルギーについて文献的考 察を加え，報告した。

6. アトピー性皮膚炎の曋症化要因の検討

国立高知病院臨床研究部 アレルギー科（小览科） ○林晶子，小倉由紀子，小倉 英郎 野市中央病院小览科

佐藤 哲也

当科では，アトピー性皮膚炎（AD）患者に対し，環 境整備と食物アレルゲン除去を基本に，薬剤に頼らな 
い治療を行っている. 初診あるいは再診した AD患者 のうち, 47例（0歳 9 例, 1 5歳 19例, 6〜14歳 7例, 15 歳以上 12 例） が平成 14 年 1 月 12 月に重症化し, その原因はダニ抗原 33 例, 食物アレルゲン 21 例， ス ギ花粉 4 例, ペット，単純ヘルペス，保湿郕，化粧品， 塩素, ラテックス, ホルムアルデヒド各1例であった (重複あり).

7. 環境調整室による重症アトピー性皮膚炎の入院療 法について

国立高知病院臨床研究部 アレルギー科（小児科） ○小倉由紀子，林 晶子，小倉 英郎 高知県総合保健協会

㞛子 德子

平成 13 年 3 月, 当院 4 階北病棟に, ダ二, 花粉など の環境抗原除去のための環境調整室が 2 室完成し, 自 宅の環境整備ができず，外来でのアレルダン診断が困 難な重症アトピー性皮虐炎患者のアレルダン診断・ア レルゲン除去による治療に重要な役割を果たしてい る. 平成 15 年 3 月までの 2 年間に入室した 15 例（乳幼 児 7例, 学童 1 例, 成人 7例) を紹介し, その有用性と 問題点およびアレルゲン除去による根治療法について 考えてみたい。

8. 香川県西讃地区小学生児童の気管支喘息罪患率調 查 -1995 年・1998年・2001年調查の比較検討一 三豊総合病院小児科

○安藤 由香, 栗生 耕太, 島内 泰宏 高知医科大学小児科

石原 正行, 高杉 尚志, 新井 淳一 脇口宏

香川県西讃地区の全小学校を対象に 1995 年, 1998 年, 2001 年に同じアンケート用紙を用いてアレルギー 疾患に関する調查を行った，回収率は各年度それぞれ 95.9\%, 94.5\% , 96.5\%であった. 2001 年の気管支喘息 䍜患率, 有病率は 1995 年, 1998 年と比較して有意に上 昇していた.小学 $1 \sim 3$ 年生の気管支喘息羅患率は調查 年度ごとに上昇し，当地区の罹患率は今後も増加して いくことが考えられた．地域別気管支喘息罹患率，有 病率は当地区南西部での増加が顕著であった.

9. 西日本小学児童のアレルギー有症率

$(1982 \cdot 1992 \cdot 2002)$

$\begin{array}{lr}\text { にしかわクリニック } & \text { ○西川 } \\ \text { 圭保小児科 } & \text { 平場 }\end{array}$

西日本小学児童アレルギー有症率調査委員会

西日本11県の同一地区の小学生を対象にATS-DLD 日本版改訂版による同一手法で 10 年ごとのアレル
ギー有症率を調查し 2002 年の結果が出たので報告す る.

全対象児童数は 20 年の間に 55388 人から 35582 人と -36\%减少していた．気管支喘息では $3.17 \%, 4.58 \%$, $6.10 \%$ と上昇し，92 年から調查したアトピー性皮膚炎 では $17.45 \%$ から 13.87\%に减少し，アレルギー性鼻炎 は $16.03 \%$ から $20.50 \%$ に上昇していた，香川県は喘息 が沖縄も含めた 11 県中最も低く，反対にアトピ一性皮 䖉炎とアレルギー性鼻炎は最も高かった。

\section{0. 松山市急患医療センターにおける気管支喘息患者} の受祅状況

松山赤十字病院小児科 ○小谷 信行, 角 勇二 松山市急患医療センター 看護師 森田 千鶴 松山市保健福祉政策課 奥村 高史 松山市急患医療センターにおける気管支喘息患者の 受診状況を集計した.

1）小児の患者が多く, 21 時から翌朝 8 時までの発 作頻発に対応できていた。

2）大半は中発作で吸入点滴で軽快していた。なか には $\mathrm{SaO} 2$ が $85 \%$ 以下の重積例もあった。

3) 二次病院搬送は少数だが，問題なかった。

4) 医療ネグレクト防止や患者家族の不安を減らす という面から一層の救急医療の充実とネット ワークの構築が望まれる.

11. 喘息発作入院患者数の 10 年間の推移及び発作原 因に関する検討

健康保険鳴門病院小児科市岡 隆男 喘息発作による入院患者数は 10 年間に半減してい たが，0〜2才の乳幼児の入院数には変化がなかった. 最近は入院患者数の季節的変動が少ない傾向があっ た. '01年 1 月〜 02 年 12 月に喘息発作で入院した 50 名 のうち 34 名 $(68 \%)$ で, 感染症が発作増悪因子となっ ていた。 そのうち9名で鼻汁中 RS ウィルス抗原陽性, 7名でマイコプラズマ抗体上昇, 1名でインフルエンザ 抗原陽性であった.感染症を伴った喘息発作入院群は, 感染症がない群に比べて入院期間が有意に長かった.

12. ゴキブリが主要アレルゲンと考えられた気管支喘 息児姉弟例

大井田病院小児科 大石 拓 症例は, 平成 11 年 10 月に気管支喘息の診断を受けた 15 歳女児と 13 歳男児の姉弟. 初診時MAST では, ア レルゲンとして考えられるものはなく，家族関係から 心因性喘息が考えられていた。喘息発作が 5 月から 10 
月に頻発するため、家族内環境を詳細に問診したとこ ろ，室内にゴキブリが多数存在することが明らかにな り CAP-RASTを施行すると 2 例ともゴキブリが陽性で あった。

13. 患をかなえる旅 ーイギリスー

医療法人社団圭保小児科医院

(前国立療養所香川小児病院呼吸器科)

平場 一美

喘息を持つ骨系統疾患 7歳男児の夢をかなえる旅に 参加した．患児は, ARDSをきたした後, 酸素吸入を 必要とし, 夜間はレスピレーターを装着している.イ ギリスまでの 13 時間にわたる飛行機の中, 酸素吸入量 を増やし，睡眠中はレスピレーターを使用した. イギ リスの人も建物も障害者にやさしく感動した，彼は， 念願の機関車トーマスに乗ることができた，一度点滴 を必要としたが，大きな問題はなく帰国することがで きた。

14. 難治性喘息の母親とその乳児喘息のこども（兄弟 例）の治療経験 一特にセレベント吸入療法につい $\tau-$

くす小児科 O久寿 正人
愛媛県立今治病院小児科
岡本健太郎, 手塚 優子, 福田 光成
渡辺小児科・麻酔科医院 渡辺謙一郎
ポートランドVAメディカルセンター
楠目 和代

母親は前回の本研究会で報告した, 致死的喘息発作 を4回繰り返した難治性喘息の症例．妊娠中から分婏 数か月後まで頻回に発作を認めたが，ラシックスの内 服（最初は持続, その後月経前後の短期）を再開しコ ントロール良好となった. その後セレベント吸入療法 を追加してからプレドニン内服も不要となった。しか し，その後こどもたち（兄弟）が乳児喘息を発症し， 治療に難渋したため, フルタイド吸入, 感染症対策, セレベント吸入などを試みている.

15. 気管支喘息の急性增悪に呼吸器感染症が与える影

高知医科大学小児科

○森澤 豊, 前田 明彦, 久川 浩章 藤枝 幹也, 脇口宏
細木病院小坚科

新井 淳一 $\mathrm{H} 14$ 年 10 月～翌年 3 月に, 喘息急性発作患者を対象. 該当者 59 例, RSV16例 (2.4 \pm 0.4 歳), M. Pneumoniae 10 例 $(6.1 \pm 1.6$ 歳), C. Pneumoniae 4 例 $(8.6 \pm 1.1$ 歳). 鼻咽腔培養で H. influenzae (HI) 21 例, S. pneumoniae (SP) 20 例検出. SPは培養陽性と陰性群間で発熱, CRP 值に有意差なし.HI陽性群は発熱頻度, CRP值が有意 に高かった。

\section{特別講演}

「小児気管支嘈息における最近のトピックス」

藤田保健衛生大学坂文種報徳會病院小览科 宇理須厚雄

気管支喘息の基本的病態は気道の慢性アレルギー性 资症とされる.これは小児期の気管支喘息にもあては まる. 気道の炎症をコントロールできる抗炎症効果が ある薬剤による治療の重要性が強調されるようになっ た.このアレルギー性の気道炎症はアレルゲンなど環 境因子の曝露によって増強することから、アレルゲン 対策など環境整備も重要なアレルギー性炎症対策とい える.もう1つの主要な喘息の病態として気道のリモ デリングが注目されている. 小巟期の喘息でも重症で は早期から観察されるという報告もある。このような 考え方は喘息治療における early intervention（早期介 入）の重要性が認識されるようになった.

本講演では，喘息治療の柱である環境整備と薬物療 法に関して最近のトピックスを概説する.

\section{招待講演}

「白血球の自律神経支配ーアレルギー発症のメカニズ ムについて」

新潟大学大学大学院 免疫学・医動物学分野 安保徹

白血球も他の細胞と同様に, 自律神経の支配を受け てその分布が調節されている. 細菌処理の顆粒球は交 感神経支配下にあり, 免疫を司るリンパ球は副交感神 経支配下にある，本来このような仕組みは身体を守る ための合目的反応なのであるが，自律神経が一方に偏 ると生体は破綻する. 肥満, 運動不足, 過保護などの 副交感神経優位の生き方が続くとリンパ球が増加しア レルギー疾患を発症する．このようなメカニズムを知 るとアレルギー疾患の治療法も見えてくる. 